\title{
Thymoma Type B
}

National Cancer Institute

\section{Source}

National Cancer Institute. Thymoma Type B. NCI Thesaurus. Code C7114.

An epithelial neoplasm arising from the thymus. It may be associated with myasthenia gravis, pure red cell aplasia, and hypog ammaglobulinemia. It includes thymoma type B1 which is a thymoma of low grade malignant potential, thymoma type B2 which is a thymoma of moderate malignancy, and thymoma type B3 which is also known as well differentiated thymic carcinoma. 